\title{
A VIEW FROM THE CONCRETE JUNGLE: DIVERGING ENVIROMENTALISMS IN THE URBAN CARIBBEAN
}

Environmental issues throughout the Caribbean have been attracting increasing concern from academics and policy makers in recent decades, especially given the vulnerability of many territories as small island developing states and the emphasis of many donor agencies on sustainable development. Nevertheless, surprisingly little is known about local perceptions of the environment and of relationships between humans and nature. While attempts are made to integrate sociocultural aspects of environmental management with technical and legal solution strategies, the focus has largely been on the rural and marine environment, notwithstanding large and growing urban populations and the urgency of urban environmental problems.

Urban Caribbean perceptions of the environment and nature are not only significant from an anthropological perspective, but they also have important implications for environmental management and policy. Effective government action is crucial to preventing and solving urban environmental problems. But where governments lack funds and skilled manpower, they cannot function without the cooperation and involvement of groups and individual citizens at the local or municipal level. To achieve civic engagement, supralocal groups - the government and environmental nongovernmental organizations (ENGOs) - must ensure that their approach is relevant to the citizens' emic understanding of their environment. Environmental organizations and policy makers tend to operate from "expert" viewpoints, while "lay" perceptions of environmental problems exist on the local level of urban communities. As Yvonne Rydin (1999:473) asserts, "it becomes difficult to achieve policy goals when a substantive gap in viewpoints exists between expert and lay constituencies and trust is absent, in part due to the previous exercise of power by the expert groups."

Various factors have served to create the gap between official readings of environmentalism and versions articulated by those living in various "concrete jungles" throughout the region. In addition, the classed and often politi-

New West Indian Guide / Nieuwe West-Indische Gids vol. 80 no. 3 \& 4 (2006):221-243 
cized nature of environmental problems in these cities complicates collective action. "Professional" environmentalist discourse often fails to reflect the worldviews and concerns held by the sizeable urban population living in the ghettos of Kingston, Jamaica, or the marginal barios of Willemstad, Curaçao. In this article I examine the disconnect between supralocal environmental discourse and policy and local understandings and articulations of environment and nature among urban residents in Kingston and Willemstad, speculating that this disconnect might be applicable throughout the broader Caribbean.

\section{METHOdS AND RESEARCH COMMUNiTIES}

The research on which this article is based is a study of actors at two generalized levels: supralocal and local. On the supralocal level I inventoried governmental and nongovernmental organizations and studied their development over time, specifically their real or potential influence on policy and on urban and environmental discourse. This research was conducted through interviews ${ }^{1}$ with strategic individuals and supplemented with an extensive analysis of written sources including numerous policy documents.

Local-level ethnographic research was conducted in four low-income neighborhoods. ${ }^{2}$ The selection of the fieldwork locations was based on their socioeconomic status and their proximity to environmental problems. Fieldwork in Curaçao took place in two locations: Wishi/Marchena and Seru Fortuna. The first neighborhood, or bario, is an area downwind from the Isla oil refinery, where rates of respiratory diseases are significantly higher than elsewhere on the island, and the second is on the edge of the city and experiencing degradation of its social and physical infrastructure, characterized by solid waste management problems and high rates of violent crime. In Jamaica, fieldwork was carried out in Riverton and Rae Town. The first community is adjacent to the island's largest landfill, while the other is an urban fishing community bordering on the city's polluted harbor and experiencing grave sewerage problems. Other criteria for selecting research sites

1. I conducted 38 interviews with a total of 43 persons in 2000, 2002, and 2003. In addition to interviews and document analysis, I took part in NGO activities such as meetings, lectures, and nature hikes. I also worked with an urban environmental NGO in Kingston in 2004 to organize a stakeholder meeting, coordinating activities and raising funds for the construction of a solid waste barrier in a gully in the downtown community of Rae Town.

2. I conducted fieldwork in 2003 and 2004. In-depth semi-structured interviews were held with a total of 118 residents (60 in Jamaica, 58 in Curaçao), supplemented by a number of unstructured interviews and numerous informal conversations. In Curaçao this took place in Wishi/Marchena in April-May 2003 and in Seru Fortuna in September-November 2004; in Jamaica in Riverton in January-March 2003 and in Rae Town in January-April 2004. 
were their physical accessibility and safety, as well as social accessibility through area leaders and key informants.

Fieldwork in these four neighborhoods consisted of participatory observation as well as semi-structured interviews with around thirty respondents per area. In one of the interview methods on which this paper is based, the photo elicitation technique (Harper 2002), respondents were presented with photos of "environmental" scenes and asked to describe how they felt about them so that I could tap into their associative thinking on some aspects of nature and environmental problems on their own island. Pictures included tropical vegetation, litter, garbage dumps, gullies, polluted beaches, and an oil refinery. The other method relevant to this paper relied on a quantitative instrument intended to roughly measure environmental consciousness. This instrument, the New Ecological Paradigm (NEP) Scale (Dunlap et al. 2000), is a scale designed to measure "five hypothesized facets of an ecological worldview." 3 The presumed facets are those relating to limits to growth, anti-anthropocentrism, balance of nature, rejection of human exemptionalism, and the possibility of an ecological crisis. The responses to these methods allowed insight into local perceptions of local nature and environmental problems, and into views on human and nature relationships in the abstract.

\section{ENVIRONMENTAL PERCEPTIONS}

Urban citizens are often seen as alienated from nature; in the Jamaican context, Elizabeth M. Thomas-Hope (1996:10) depicts the situation as follows:

Children in Kingston's so-called "garrison" communities, where green is the colour of a political party, not of vegetation, grow up in an environment devoid of nature. The power which they assert over their own environment reflects inner anger rather than positive interaction.

3. The instrument consists of 15 statements, and respondents are requested to indicate whether they strongly agree, mildly agree, are unsure, mildly disagree, or strongly disagree with these statements. Each hypothesized facet is tested with three statements. Responses to the statements were coded from 1 to 5 , so that a higher score denotes a pro-NEP response. With 15 statements this means that a total score of 75 indicates a complete endorsement of the NEP, and 15 indicates complete rejection. Despite quantitative limitations, the NEP scale is useful because of its extensive use and the consequent comparability of samples. During my second period of fieldwork I used an adapted version of the scale, incorporating several changes that I believed would improve it for the Caribbean context. These changes basically simplified some of the language and added a dimension measuring religious beliefs. Combining the data from all communities (including only those items used in both scales) results in larger samples and allows comparisons between Jamaica and Curaçao as well as a "Caribbean" sample of all respondents combined, as displayed in Table 1 on p. 229. 
I believe this to be an overly pessimistic portrayal; urban settings, even those that are poor or violent, can foster positive attitudes toward nature and the urban environment. On the whole residents in all four research neighborhoods had definite ideas on the natural and urban environment in their concrete local manifestations, with a number of prominent themes. Those discussed here are evaluations of "wild" nature and brown environmental problems.

\section{Wilderness}

A salient theme was the mixed attitude respondents had toward wild nature, generally qualified as bush in Jamaica and mondi in Curaçao. The bush is seen simultaneously as dirty and dangerous, a place of beauty and peace, a national symbol, and an economic resource. Many Jamaican respondents, especially in Riverton, displayed an aversion toward wild nature such as mangroves and cacti, and feel that bush is "bad" or "dirty," full of mosquitoes. They feel that these places "wan' develop" or "would look good if it clean up." It is interesting to note that wilderness is seen as dirty, it "jus' look bad, not clean." In this sense bush is a negative valuation, thus a scene can "look nice although it bushy." In Curaçao, Wishi/Marchena residents in particular displayed a marked aversion to the mondi, exemplified by wild and undeveloped nature such as the island's cactus landscapes. This wilderness was associated with danger, whether it was the prickly plants, wild animals, or lurking rapists and drug traffickers. In addition, a number of respondents portray themselves as people who do not venture outside the urban area. Speaking of the desolate seaside on the island's north coast, one resident explained that "I don't go those places, I'm more a city person," while another concurred that he did not really go to "these places, with nature." Some Wishi/Marchena residents ascribed positive qualities to the mondi and other natural tableaux, while excluding themselves in this appreciation. They did note that others, namely "nature lovers" or tourists, would value it: "this is nice if you like flora and fauna" or "this is a place where nature is intact - it's good for animals and nature lovers." This noninclusion of the self in the appreciation of nature might mean that respondents recognize its value but feel no personal attachment to it.

However, many Jamaican and Curaçaoan respondents do value "wild" or "not spoilt" non-urban places. Respondents on both islands voice their appreciation for the beauty, coolness, fresh air, and quiet provided by tropical vegetation. Residents also realize the growing scarcity of wilderness - "wi would like some of our environment to remain like this." This sentiment is reinforced by their urban perspective. In Jamaica, natural, green areas are also seen as an integral, symbolic part of the nation and are associated with "country" and nice, quiet places. Jamaicans in Rae Town praise the ecological functions of wild nature; mangroves, for instance, are appreciated for protecting young fish and birds, presumably due to the community's close relationship with the harbor and the sea. In Curaçao, the mondi is also appreciated by some for its 
utility value, as "a good place to hunt iguanas." Residents in the Curaçaoan community of Seru Fortuna displayed the most positive attitude toward bush or mondi. They nearly unanimously described the mondi as pretty and nice (dushi). Moreover, bush is seen as being symbolic of Curaçao as a nation: "when you see it you know you're in Curaçao." The mondi and its plants represent Curaçaoan traditions and heritage. Many people were able to name various typical mondi plants and their medicinal and culinary uses. Like other forms of heritage, "we need to conserve it." This lack of a negative association with bush is probably due to residents' proximity to and interaction with it. These barios are basically surrounded by bush, and the residents interact with it in differing ways. Many men and boys go fishing along the coast for fun and to supplement their diet and income, while women praise the calming effect of being amongst nature and plants. In addition, Seru Fortuna has a rural past that involved intimate use of mondi resources.

Many respondents in all neighborhoods acknowledge and emphasize the instrumental value of natural resources, the "green" environment, above their intrinsic value. The Curaçaoan mondi is a good place to hunt iguanas, a place that provides medicinal products and is attractive for tourists. Its attraction for tourists is reflected in the statements respondents made about garbage piling up on beaches: "this is dirty, it's not nice for tourism" and "tourists shouldn't see this." Jamaicans know that mangroves can be used to make mats and hats, cacti are used to make medicine or wash hair, trees are valued for their fruit. Residents place a high value on self-sufficiency, and knowing how to make the most of one's environment is integral to this.

Despite the utility value of the bush or mondi, the preference for development above unspoiled nature is reflected in the overwhelmingly positive evaluation of industry, such as an oil refinery, which is associated with jobs and development, "progressive, money-making thing." Industrial development is associated strongly and positively with economic progress, though it is noted in Curaçao that the sociospatial distribution of benefits (money) and disadvantages (pollution) is skewed.

\section{Brown Environmental Problems}

Respondents in the research neighborhoods in Curaçao and Jamaica were unanimous in their aesthetic, hygienic, and environmental objections to brown environmental problems, most prominently litter and garbage. They expressed strong objections to the omnipresence of garbage and litter and

4. These references to tourism and utility value somewhat replicate the findings of De Kruijf and Arends in Curaçao three decades ago. They noted that "there is not interest at all in nature except for practical aspects" and also observed the tendency to place the blame and responsibility for environmental management and mismanagement almost completely on the government (De Kruijf \& Arends 1975:211). 
reacted emotionally to its visibility in both urban and rural areas throughout the island. It is considered a visual disturbance through its ugliness, but more importantly it is a health hazard: the cause of rats, roaches, and disease. In Rae Town, where garbage-clogged gullies flood following heavy rain, residents worry about the drains' smell and pathogenic qualities, as well as the danger to people living on their banks. They do recognize the hypocrisy of outcries that follow such a flood: "people a go cry ... same likkle people who literally do this [dump garbage in the gullies]." Respondents also recognize the ecological impacts of improper solid waste management as it is simply "wicked to the environment."

Many link waste management issues to socioeconomic factors such as poverty, crime, and social disintegration. Curaçaoans call this type of pollution "illegal" and "unhygienic" and associate it with neglect and social decline: crime, drug addicts, prostitution, and houses abandoned following large-scale migration to the Netherlands. In urban areas, litter is associated with the bad name certain barios have and is blamed on poverty and sometimes foreigners, especially Dominicans. In less populated areas, where illegal dumping is very common, the blame is placed on "a lack of civic feeling." Respondents also place a strong emphasis on the importance of image in a tourism-dependent country, wishing that the people who dump illegally would at least hide their dead dogs and old appliances in the bushes rather than leaving them by the wayside where tourists can see them. Jamaicans ${ }^{5}$ condemn litter and illegal dumping as "nasty," "awful" or "very, very sloppy" and associate it with poverty and crime: "these [rundown urban] places need refurbish, build back, beautify the city. Dis a safe haven for criminals." Unclean surroundings are linked with poverty, abandonment, and a lack of development, and look "like it condemn." Cleanliness is also associated with wealth. For instance, the commercial area of downtown should look better "cause money mek dung deh," because money is made down there. There appear to be strong normative ideas about what belongs where in Jamaica: rubbish should not be in evidence in rural areas, just as cows are not supposed to roam on garbage dumps: "dem cow fi deh inna pasture," those cows should be in a pasture. Especially given respondents' positions in the heart of urban Jamaica, strong value is placed on clean, green spaces that are removed from the city's poverty and filth. ${ }^{6}$ Pollution does not fit well in respondents' views of the countryside. They assume that "is same people from Kingston do this" and find it improper "fi a place weh tourist always go."

5. See Chevannes and Gayle 1998 for a detailed report of inner city perspectives on solid waste management.

6. Notwithstanding the prevalence of rural poverty in Jamaica, urban Jamaicans often speak highly, and with some wistfulness, of the country areas. Though people "down a country" are seen as a little backwards, rural Jamaicans are also seen as more peaceful, with traditional values (see Headley 2002:60-62). 
Garbage and litter are accepted as a part of urban life, but are nevertheless regarded as plain wrong and dirty. This strong condemnation appears hypocritical given that all neighborhoods have vacant lots or empty houses that function as places where garbage is dumped freely. Riverton borders on the dump, and the presence of garbage there is noticeable at all times. ${ }^{7}$ However, residents' strong emphasis on hygiene is evident in the care they take of their own houses, yards, and personal belongings, pointing toward different attitudes regarding public and private space.

The data presented above emphasize the interconnectedness of ecological issues and social, economic, and political concerns, including poverty and crime. Ecological, social, economic, and health concerns are seen as interwoven, while a "good environment" encompasses the social, physical, and natural environment. ${ }^{8}$ Residents underline the instrumental value of natural resources: this too is an expression of the interconnectedness of environmental and other concerns, in this case economic. In Curaçao, garbage is linked to poverty, social disintegration, and crime; the oil refinery is associated with economic and social inequality; and a deficient infrastructure, ranging from overflowing cesspits to unpaved streets, is seen as indicative of the communities' marginal social and economic position. In Jamaica, residents also recognize the role of urban politics in the consistent neglect of ghetto areas: the bad reputations of their neighborhoods are the reason that environmental problems are not tackled, and this is why improvements in the physical infrastructure - housing, streets, lighting - are so slow. Apart from the sociopolitical context, they see social disintegration as going hand in hand with environmental and physical deterioration, and they display a strong awareness of the social aspects of urban environmental problems. ${ }^{9}$ The relationship between environ-

7. A notable tendency in Riverton, stemming from residents' informal waste management activities, is to see the economic value of garbage. Riverton residents regard the dump itself and the accumulated piles of garbage lining their own streets as sources of income rather than pollution. Nevertheless, they are disturbed by litter on the streets of other urban neighborhoods, or in rural areas. Objections to garbage are situational, affirming Mary Douglas's (2002) well-known categorization of pollution or dirt as "matter out of place." 8. The linking of environmental problems to socioeconomic issues is reflected in a qualitative study conducted amongst lower-income Jamaican youth in the context of an environmental education campaign. The study also found that any interpretation of environment includes social aspects; all definitions of "good environment" referred to peace and unity. To the majority "environment" was defined as "what they saw in their surroundings: their community, people and their behaviour (including 'war'), the state of the infrastructure, living conditions, flowering plants, painted and decorated corners, buildings, trees and animals" (NEEC Campaign Protest Report: A Qualitative Assessment, Hope Enterprises, Kingston, 1999).

9. Dodman (2003:311) also found that in Kingston, "citizens from across the socio-economic spectrum shared the perspective of these environmental problems as problems of social organisation." 
mental degradation and human health was stressed repeatedly. Residents on both islands displayed a considerable awareness of the health impacts of dust, smoke, and other air pollution, and of the unhygienic circumstances of a dysfunctional sewage system.

Respondents see environmental and other urban concerns as interwoven, basing their view on concrete experiences in their personal surroundings; an example from Rae Town is as follows. The gullies are clogged and full of vermin because people throw garbage into them, either because they are "bad mind" (social) or because they do not receive proper garbage collection (environment). Others dump bags of feces there because they have no proper toilets (infrastructure, poverty). Children in Rae Town become ill (health) because they play in the polluted gullies (environment). However they might not be playing there if there were better places to play (infrastructure) or if their mother had enough money (economy) to send them to school. But it is hard for adults to find work because of area stigmatization (crime). This inability to secure a legal income forces people to look to their family and friends (social) or politicians (politics) for support, or to resort to illegal options (crime).

\section{FOLK ECOLOGIES}

Curaçaoan and Jamaican residents display coherent folk ecologies or "general beliefs about the Earth and human-environment relationships" (Stern et al. 1995:738). These sets of beliefs, also known as environmental worldviews, are intimately connected to religious beliefs and a fairly pessimistic view of humanity in general. There was a large measure of concurrence between responses on both islands and in all four neighborhoods. Quantitative data on various facets of an environmental worldview, obtained using the NEP scale, are displayed in Table 1 (p. 229), while I discuss the qualitative data generated by the same scale in this section. A higher score on the scale indicates a stronger presumed support of each of the five dimensions of the hypothesized pro-environmental paradigm, that is, a higher level of environmental awareness according to this standardized scale.

The idea that there is a limit to the space on earth and to its resources is met with resistance by nearly all those interviewed. The earth is viewed as being a vast expanse, and nature is conceived of as limitless, an endless horn of plenty. In the words of Jamaican respondents, "Father God nah put no limits innit" and "If it neva nuff wi woulda died long time." Similarly, respondents do not envision a looming limit to the number of people; overpopulation is not an issue. The sense of overcrowding and fear of overpopulation encountered in other densely populated or highly urbanized regions is remarkably absent. Several people stressed that scarcity throughout the world stems not from overpopulation, but from the fact that its natural wealth is not 
Table 1. Means of dimensions of NEP scale $(1=$ strongly anti-NEP and $5=$ strongly pro-NEP)

\begin{tabular}{lrrrrrr}
\hline & \multicolumn{2}{c}{ Jamaica $(\mathrm{n}=60)$} & \multicolumn{2}{c}{ Curaçao $(\mathrm{n}=56)$} & \multicolumn{2}{c}{ total $(\mathrm{n}=116)$} \\
& mean & $\mathrm{SD}$ & mean & \multicolumn{1}{c}{ SD } & mean & SD \\
\hline limits to growth & 1.81 & 1.00 & 2.05 & 1.04 & 1.93 & 1.02 \\
anti-anthropocentrism & 2.80 & 1.11 & 3.10 & 1.30 & 2.94 & 1.21 \\
human exemptionalism & 3.55 & 1.03 & 3.58 & 0.82 & 3.56 & 0.93 \\
balance of nature & 4.00 & 1.03 & 3.75 & 0.98 & 3.88 & 1.01 \\
possibility of an ecocrisis & 4.28 & 0.91 & 4.46 & 0.72 & 4.36 & 0.83 \\
NEP score total & 48.31 & 8.28 & 49.22 & 8.94 & 48.75 & 8.58 \\
\hline
\end{tabular}

shared, not distributed equally by those in power. There is a strong trust in technology, which will enable humans to continue to utilize natural resources; most believe that eventually people will be able to control nature, though not necessarily for the better because people "abuse their knowledge and power." The perfidious nature of humans, who are severely abusing the environment, is not subject to much debate. In Curaçao, they chop down trees, beat iguanas, burn down the mondi, build houses indiscriminately, all without thinking of the consequences, and sometimes "they do it even when they don't have to." On both islands, humans are seen as wicked, greedy, and envious.

Along with this misanthropic view of mankind, residents on both islands presented an anthropocentric view of nature. The general opinion is that humans were created by God to rule over the rest of nature. Quoting the Bible on this (and many other issues), respondents state that God or Jah granted man dominion over all things. ${ }^{10}$ This hierarchy is seen as a "natural" logical order. As one Jamaican respondent put it, "lion rule di jungle, man rule di earth." This dominion entails humans' right to use and change the natural environment to suit their needs, though some Jamaicans demur that "some places haffi remain [untouched]" or even that "Father put dem deh so dem nah fi change it." "11 Their view of nature is largely utilitarian: most are convinced that plants and animals exist in the first place to be used by people, though many add the restriction that humans need to make use of them in a prudent manner, as dominion entails a certain responsibility or stewardship. These convictions have a religious basis: "God created animals to be eaten, but you need to use them for good things, you can't just kill them for fun."

10. Bob Marley's song "We and Dem," quoted by one Jamaican respondent, talks of humans' God-given right to rule over nature and their subsequent abuse of this right: "But in the beginning Jah created everything/giving man dominion over all things/but now it's too late, you see men have lost their faith/eating up all the flesh from off the earth."

11. That is, God made those places so people should not change them. 
Correspondingly, many feel that humans have the right to change the natural environment to suit their needs, but only if these changes are made with consideration: "not without a good plan, you can't hurt nature."

Most respondents rejected the idea of human exemptionalism. Are humans seen as special and different from the rest of nature? In the main, Curaçaoans and Jamaicans saw humans as part of nature in the same manner as plants and animals, and as comparable to animals in many ways. Many explained their stance by saying that all were created by and under God or Jah. According to them, there is a hierarchy, though: "people are the part of creation God loves most." Several people were quick to provide examples of animals communicating with them, while one Curaçaoan was emphatic that "trees cry just like us." Animals were said to have feelings and thoughts similar to people - "dem come in jus' like wi"12 as one Jamaican put it - but lack speech. The endowment of animals with a spirit concurs with Barry Chevannes's (1994:26) statement that the Jamaican view of nature is "concrete rather than abstract, manifesting itself in important animistic beliefs about natural objects and products." These beliefs do not just apply to animals, as Jamaican artist Sizzla sings: "every flower in the garden, every tree in the forest represents a living person." 13 Respondents also stress the interconnectedness between humans, animals, trees: "If air polluted, they die, we die."

Still, nature is generally conceived of as strong enough to cope with human impacts. Many see nature as unalterable, uncontrollable, and indestructible: it is "God's work," and "only Him up there" can change it. Along the same lines, nature is generally envisioned as being very robust, stronger than humans and with a powerful regenerative capacity. In the case of fishermen in Rae Town and Seru Fortuna, this reasoning is perhaps the result of frequent interaction with the wild elements out at sea.

The link respondents make between the natural and the supernatural, which is evident in the idea of nature as imbued with an uncontrollable, divine strength, also emerges in discourses on natural disasters. There is a strong belief in the threat of an ecological crisis, a somewhat millenarian expectation of environmental catastrophe..$^{14}$ Respondents believe disaster is imminent as a result of human interventions in nature, but they also explain their concern as the fear of a reproving deity. They illustrate the direct relationship between interference with nature and disaster with the example of

12. That is, they act just like us.

13. In the song "Jah Will Be There," from the 2002 album Ghetto Revolution, on the Greensleeves label.

14. I am inclined to attribute this in part to the more general, religiously inspired, Caribbean belief that disaster will not be long coming, a certain apocalyptical preoccupation combined with the region's history of natural disasters including devastating earthquakes, hurricanes, and flooding. For more on the cultural construction of natural hazards, see Bankoff (2004). 
Curaçaoan land reclamation, which is followed by regular flooding, or the drought that follows deforestation in Jamaica. But respondents are fervent in their explanations of natural disasters as indications of divine wrath, as punishment for moral failure. For Curaçaoans, "God is angry because of the lack of values, the murders." Visions of an apocalypse were perhaps strengthened by Hurricane Ivan, which swept a devastating path through the Caribbean in September 2004 but barely missed Curaçao. Jamaicans also link hurricanes and the murder rate, explaining that "[God] nah like weh wi do." But the direct relationship between interference with nature and resulting disaster, without divine intervention, is also recognized. Illustrations of this included the concrete Curaçaoan example of land reclamation followed by regular flooding, or in Jamaica the drought that follows deforestation.

Religion, whether Rastafari, Protestantism, or Catholicism, obviously plays an important role in shaping ideas on the relationship between humans and nature. ${ }^{15}$ Nearly everyone feels that God is a determining factor in the relationship between the two; the hierarchical relationship between humans and nature is mediated by a God figure. God is seen as laying the foundations for the relationship between humans and their environment, though He leaves the responsibility to humanity; there is an equilibrium between structure and agency. As Curaçaoans noted, "there's a balance between what God made and what we do with it." "Humans decide - God put man here but it's up to man to choose wisely," is how one Jamaican respondent put it. Another had a slightly more pessimistic view: "God nah stop us, he lef us to mek wi own destruction."

Religious views are expressed in a worldview that links the natural and the supernatural. ${ }^{16}$ We find related views expressed by Chevannes, who describes the view of mankind in Jamaica as dialectical. Humans are seen as actors "capable of mastery over the supernatural, the natural and the human world," mainly through the acquisition of knowledge. But simultaneously, they are seen as passive and subject to supernatural and natural forces, the latter being interpreted as instruments of divine action (Chevannes 1994:32-

15. Despite the dominance of especially Protestant Christianity in Jamaica, it is likely that Rastafari, as a socioreligious movement, has had a substantial impact on environmental thinking. A central idea for Rastafari is ital livity, "a commitment to using things in their natural or organic states" with an emphasis on harmony between humans and nature and a rejection of the artificial in favor of the natural (Edmonds 1998:354). While only a minority of Jamaican respondents were Rastas, in their discourse on nature and environment many of them expressed "conscious" attitudes and opinions akin to those propagated by Rastafari.

16. Despite considerable religious diversity amongst respondents - who included Catholics in Curaçao and, in Jamaica, Rastafari and adherents of different Protestant denominations - there was remarkable agreement on these issues, across islands and faiths. For more on various religious traditions and thought on these and other Caribbean islands, see for instance Austin-Broos 1997, Taylor 2001, Desmangles et al. 2003, Streefkerk 2003. 
33). This idea of natural forces as wild, infinite, animated powers ties in with more general animist ideas, which are also apparent in the perception of plants and animals as having spirits or communicative powers similar to humans. Simultaneously, respondents display an anthropocentric view of humans, whom they see as operating at a level superior to that of nature. They are destined to rule over nature and are capable of destroying it and can develop all kinds of technology in order to manipulate their surroundings, sometimes to ill effect, as with genetic manipulation, which was strongly condemned by those respondents who spoke of it. Humans' greed and disregard results in environmental abuse, as witnessed for instance by widespread pollution. These seemingly contradictory beliefs are structured in a trinity of humans, nature, and God/Jah, in which nature and humans are positioned under God/ Jah who is the Creator of both. As a result, respondents display a worldview shaped by African-Caribbean Christian and Rastafari beliefs, distinguished by a creolized mixture of misanthropy, anthropocentrism, and animism. Such a worldview corresponds partially with western concepts of environmental consciousness, though it excludes the dimensions of "limits to growth" and to a lesser extent "anti-anthropocentrism" (see also Table 1, p. 229). In their "folk ecologies," respondents in both cities consistently demonstrate significant environmental awareness. Though they may not always use western or scientific terminology, they have strong ideas on what is and is not "pretty for the environment."

\section{PERCEPTIONS OF THE ENVIRONMENT AND NATURE IN THE CARIBBEAN AND BEYOND}

In Caribbean studies an extensive debate on the meaning of land, with special reference to the case of family land, has developed. ${ }^{17}$ A number of works dealing with this debate have associated Caribbean attitudes toward land with attitudes toward the environment (see Potter 1992, 2000, Skelton 1996). Abramson (2000:1-2) notes that land can be seen as "a resonant expanse of distinctive representations, meanings and experiences"; his statement that "in all of its human settings, land appears both as an object with use-value and as a symbol with meaning" could not be more apposite in the Caribbean. The data presented here support the argument that dual, ambiguous attitudes toward land are replicated in attitudes toward nature and the natural environment. Furthermore, these attitudes are entangled with religious and other supernatural beliefs. Literature on this topic is rather scarce, but tends to confirm my premise. On the one hand, nature has a "friendly" face. The

17. See Clarke 1957, Lowenthal 1961, Besson \& Momsen 1987, Crichlow 1990, 1994, Barrow 1992, Skelton 1996. 
natural environment is represented as a bountiful cornucopia, there for the purpose of human utilization and development, a perspective with roots in Judeo-Christian religious thought. Concurrently, nature is seen as threatening and unpredictable, a wild force over which humans cannot exert control. Supernatural elements are a factor in the construction of this view.

The sea, a prominent element of the natural environment in any Caribbean country, is illustrative of this relationship. The sea is seen as an inexhaustible source of fish, and thus of food and wealth. A lack of expensive high-tech equipment and the absence of economies of scale have meant that most fishing in the Caribbean is of an artisanal or subsistence nature, rather than taking the form of large-scale commercial enterprises (McKee \& Tisdell 1990:12324). As a recreational domain, the sea finds far less favor. Although many people live close to the shoreline and may frequent the beach regularly, swimming is not a popular pastime, especially not in areas with a lot of waves, and many do not know how to swim. Despite a traditional attitude of trepidation, the economic mandates of tourism have brought about a greater involvement with the sea, while individuals employed in seaside tourist activities attest to the enjoyment it can bring (see Gmelch 2003).

Bert Verheij (2001) encountered a similar situation in Saba, where an economic mindset combines with an attitude of respect toward nature. Sabans articulate a three-tiered, context-dependent perception of nature. At the most abstract level, nature is pictured as an encompassing system and a godlike entity. At a less abstract level, nature manifests itself in hurricanes and other weather phenomena. These manifestations are seen as direct proof of the existence of the godlike entity. At the most concrete level, nature is conceived of as "things that are supposed to be," including Saba itself, the sea, and the sky.

Gail Ringel and Jonathan Wylie (1979) found in Dominica that foreign, western concepts of environment "including ideas of conservation and natural beauty" were not easily accepted. The researchers found that attitudes toward nature are shaped by religion: nature is seen as part of a system which focuses on humankind's relationship with God. The environment consists of three realms: the natural, the social, and the supernatural, the latter controlling all. Fishing, for instance, has both social and religious aspects: a good catch is proof of the generosity of God, but too much fish will inspire the jealousy of neighbors. The sea is again seen as abundant, inexhaustible: "overfishing is inconceivable. Surely God could send more fish if He wanted" (Ringel \& Wylie 1979:44). Undeveloped areas are seen as ugly and/or sources of profit. This attitude toward wild areas is similar to ideas I encountered decades later in Curaçao and Jamaica. Their results led Ringel and Wylie to view the church as the institution most likely to foster an environmental ethic.

Jean-Luc Bonniol (1979), studying the tiny, arid island of Terre de Haut des Saintes, near Guadeloupe, found perceptions of the island environment were related to material activities. Similar to my respondents, residents held 
a pessimistic view that their island would eventually be submerged. In a recent study researchers examined environmental attitudes among university students in Trinidad, the Dominican Republic, and the United States. They found that Trinidadians and Dominicans held strong pro-environmental attitudes, indicating stronger feelings of ethical responsibility and a greater appreciation of beauty in nature than North American students. However, the two Caribbean groups also believed strongly that natural resources existed for human use; they understood humans to be rulers over nature and users of animals (Rauwald \& Moore 2002). Though the study used an elite sample, the seeming contradiction in environmental attitudes seems typical of a Caribbean duality in thinking on nature and the environment.

Caribbean environmental values, attitudes, and worldviews diverge from environmentalism as conceptualized, and compartmentalized, in Europe and North America. Environmentalism, both as a movement and a set of values, displays a large measure of variety, but a majority of authors conceptualize the diversity within environmentalism as a continuum (Williams \& Millington 2004, Nadasdy 2005). The spectrum of environmental discourse and practice, seen as akin, but not tied, to the range of political orientation, extends from a more conservative to a more radical pole with intermediate positions between the two extremes.

Caribbean environmental thought, as presented in the data here and as encountered in the literature, does not conform to a scaled format. In certain respects, perceptions parallel the western concept of environmental consciousness: humans are seen as part of nature, while spiritual and communicative powers are attributed to plants and animals. Nature is revered in the sense that it is seen as strong and wild, and associated with supernatural powers. The degradation of the natural environment that humans cause is a serious concern, in particular the ecological catastrophes that may follow. However, Caribbean worldviews place a strong emphasis on the instrumental value of natural resources; the concept of a limit to growth is largely absent; and humans are seen as possessing a God-given right to dominion of the earth. Relations between humans, nature, and God/Jah are articulated in worldviews characterized by a combination of misanthropy, anthropocentrism, and animism. Western academic and policy discourses on environmentalism do not generally intertwine religious and environmental beliefs in such a way. The fact that Caribbean beliefs do not fit on a certain scale or into an extraneous mold does not automatically mean that respondents to my interviews should be classed as environmentally "unconscious." Rather, it implies that, as research on environmentalism is expanded to studies addressing sociocultural diversity, the idea of the spectrum and of the fixed constellations of values, attitudes, and beliefs must be reconsidered. As Linda Kalof et al. (2002:14) assert, "no longer can we assume that there is one set of values, beliefs, and perspectives that represent human concern for and 
maintenance of the environment but rather [we] must look for structural differences in environmentalism."

\section{GREEN PROFESSIONALS}

The perceptions of and discourse on nature and the environment encountered in Jamaica and Curaçao, so similar to those observed elsewhere in the Caribbean, diverge from "professional" versions of environmentalism. The latter, "expert" versions, circulate both globally and nationally, within what can be termed an ecological "epistemic community." Such communities are knowledge-based networks whose members are linked by specific technical - often environmental - expertise, but who will also share a set of normative and principled beliefs, causal beliefs, discursive practices, and a "policy project." They influence policy through the diffusion of technical knowledge, and of norms, values, and specific terminology (see Haas 1992)..$^{18}$ Caribbean environmental professionals within governmental and nongovernmental organizations may themselves be part of such ecological epistemic communities, or at least be influenced by the environmental values, attitudes, discourse, and policy strategies these knowledge-based networks disseminate nationally and internationally.

The divergence between professional and lay environmentalism in the Caribbean lies in a number of factors. A first difference relates to the environmental worldviews encountered in the research communities. Caribbean lay environmentalisms should not be located automatically on a continuum from environmentally aware to environmentally unaware. While certain aspects of Caribbean environmental thought coincide with western concepts of what environmental awareness is, others strongly reflect a specific, creolized cosmology in which the natural and the supernatural are entwined. Yet environmental professionals continue to echo the Euro-American idea of a continuum, stressing the necessity of local awareness-raising and environmental education. The professional notion of environmental consciousness is based strongly on scientific fact or consensus, such as measurable ecosystem degradation or pollution levels and established causal patterns in human and nature interactions. While detailed science-based analyses of degrading natural resources will be more effective in spurring government action, the religious beliefs that guide much of lay environmentalism are negated in such rational, technical discourse.

18. See also George Kemi, "Framing Scientific Claims to Resonate with Developmental Pressures in Lesser Developed Countries: Biodiversity Management in Cockpit Country." Paper presented at UWI, Mona conference "Global Change and Caribbean Vulnerability: Environment, Economy and Society Risk?” Kingston, July 17-21, 2006. 
A second difference is that supralocal actors tend to articulate environmental problems as a separate domain, rather than integrating these issues with social and economic issues. Additionally, their emphasis remains on green environmental problems. At the level of Jamaican and Curaçaoan government and environmental organizations, most efforts go toward green issues, including biodiversity, the marine environment and coral reefs, and nature conservation within a framework of sustainable tourism. The disposition toward this type of environmental problems is clear in governmental policy documents ${ }^{19}$ and ENGO campaigns and websites. The islands' governments do attempt to tackle issues related to wastewater, energy, waste management, and industrial pollution. However, both governments have had financial interests in industry, utilities, and environmental services, which have greatly complicated matters. Most ENGOs tend to focus on less "dirty," more attractive issues. For the most part, government and ENGO portrayal of environmental problems and sustainable development remains distant from the specific priorities of the lowincome urban population. ${ }^{20}$

The strong accent placed on the green environmental problems reflects the importance of tourism, a sector which in the Caribbean relies heavily on an image of pure, unspoiled nature and the appeal of mainly coastal and marine natural resources. Apart from economic concerns connected to the tourist industry, supralocal actors support and are influenced by the globally predominant green agenda, which generally prioritizes environmental issues with effects that are dispersed, in that they are not merely local, and delayed, in that they will affect future generations. Problems ranking high on this green agenda tend to be those that impact mainly on ecosystem health, and the scale at which they operate is global or regional. Its focus stands in contrast to the brown agenda, which prioritizes local, more immediate environmental issues. Brown environmental problems affect mainly the poor and their influence is primarily on human health (McGranahan \& Satterthwaite 2002). Whereas

19. For relevant policy documents see Nota duurzaam toerisme van het natuur-en milieubeleid van de Nederlandse Antillen 1996-2000, 1998; Voortgangsrapportage van de Contourennota van het natuur-en milieubeleid van de Nederlandse Antillen 1996-2000, 1999; Natuurbeleid van de Nederlandse Antillen: Aan de dageraad van een nieuw millennium 2000-2005, 2000; Meerjarenplan milieu- en natuurbeleid Nederlandse Antillen 2001-2005, 2001; Nature and Environment Policy Plan Netherlands Antilles, 2004-2007, 2004, Vomil/Mina (Ministry of Public Health and Social Development, Department of the Environment); JANEAP (Jamaica National Environmental Action Plan) 1999-2002, 1999; JANEAP: 2002 Status Report, 2002; National Environment and Planning Agency; Jamaica State of the Environment Report, 1998, National Resource Conservation Agency, Kingston.

20. The prioritization of conservation by Jamaican and Curaçaoan organizations appears to be typical of the Caribbean (see Jácome 2006). 
professional environmentalists principally pursue green agenda issues, urban residents tend to be far more concerned with brown agenda problems.

The next important difference relates to socioeconomic and ethnic features associated with the proponents of different forms of environmentalism. The green environmental concern of professional environmental actors in Curaçao and Jamaica reflects the elite status many of them have; a considerable number are foreigners, while others have enjoyed foreign education or training. Their discourse and activities indicate an awareness of, and engagement with, terminology and priorities that are dominant in global or perhaps "western" environmentalism and that are dispersed by ecological epistemic communities. At the ENGO level, a gap between their members and the majority of the urban population is evident. Actors are mostly middle-class or foreign, and often light-skinned. In Jamaica, many environmental organizations are headed by either foreigners (including a number of expatriate Americans) or by unmistakably upper-middle-class, often light-skinned Jamaicans (see Carrier 2003). In Curaçao, the number of Afro-Curaçaoans in the environmental movement is fairly limited, certainly as the leaders of organizations. Some environmental NGOs have White Curaçaoan members, while a significant number of groups were founded by European Dutch who were not born on Curaçao but settled there for various reasons. It is plausible that displaying an interest in, and commitment to, conservation and other green issues has become a local form of Bourdieuan class distinction or symbolic capital acquisition.

Additionally, supralocal prioritizations result from the green pressure exerted by donor countries and international financial institutions on Caribbean governments and NGOs. Environmental protection has been a popular donor target for earmarked aid, including debt-for-nature swaps, a construction applied in Jamaica. Environmental organizations in Curaçao are to a large extent dependent on the Dutch government for funding, whereas in the Jamaican situation the best-funded organizations are those with access to international funding, whether bilateral, multilateral, or nongovernmental. The implications are similar on both islands: "the interests of these international organizations determine which of the NGO activities are funded, and by extension which NGOs survive at an operational level."21

Increasingly, international aid is directed from government to nongovernment organizations. The channeling of donor funds to NGOs is based in part on the assumption that these organizations work more effectively through participation and are more representative of the communities the funds are supposed to assist. Patricia Lundy (1999) argues that in the case of Jamaica, these are mistaken assumptions because ENGO members are overwhelmingly

21. M. Witter, Report on a Survey of NGOs in Jamaica. CSEDNET (Caribbean Sustainable Development Network), 2002. 
well educated and middle class; ENGO activities reflect the concerns and priorities of local elites, thus inadvertently reinforcing inequality in social relations. This view concurs with what I encountered while researching and interviewing organizations in Kingston and Willemstad. Although the leaders and members are usually extremely well-meaning, hard-working, idealistic individuals, it is not hard to discern something of a condescending attitude toward "the community." The president of one ENGO describes how "many in Jamaica do not have an appreciation of nature - they do not comprehend the relevance of lizards, insects and plants (except in the light of economic gain) and have to be assisted to 'see' the wealth and beauty of our island" (Levy 1996:25, emphasis added). In Curaçao, one of the more successful ENGOs, led by a Dutchman, has as its slogan konosé bo isla, "know your island." Interestingly, the use of Papiamentu in this motto contrasts with the organization's general orientation toward the Dutch language. More strikingly, the depiction of the local population as insufficiently knowledgeable - or appreciative - of its own island shares similarities with what the Jamaican ENGO leader said about that island's population.

The mandate of "educating the masses" is sometimes close to being a subtle form of environmental neocolonialism, especially since the difference in environmental prioritizations is added to a difference in actors' socioeconomic and ethnic backgrounds. As a result the environment is seen as the domain of foreigners and the light-skinned elite, especially as long as they focus principally on green issues and refer less to the brown issues to which the majority of urban citizens relate on a day-to-day basis.

\section{IMPLICATIONS}

While authors such as Kay Milton (1996) describe environmentalism as a "transcultural discourse" capable of crossing cultural boundaries, such an approach negates the power grid underlying environmentalist transmissions and translations. Professional environmental discourse encountered in Jamaica and Curaçao is an elite phenomenon, interwoven with the specific socioeconomic and ethnic constellation of these Caribbean societies. This discourse, with direct implications for environmental policy and management, cannot be considered as separate from international epistemic communities and financial incentives. Global flows of information, power, money, and people impact forcefully on environmental organization and management at the level of Caribbean society, including a progression toward "donor-driven sustainability." To date, locally oriented grassroots environmental groups have not developed a significant presence in the countries studied here, perhaps because of their small populations, perhaps through a state tradition of co-opting local-level leadership into the political system. Conversely, a 
traditionally global orientation on the part of Caribbean elites might explain the locally based, but globally oriented environmental elites of Jamaica and Curaçao, who promulgate their version of environmentalism through education, management, and policy strategies. It is my contention that part of the reason these strategies have proved largely unsuccessful, is that this professional environmentalist discourse clashes with the worldviews and experiences of environmental problems - related to pollution, poverty, and social disintegration - in the barios and communities. The Jamaican and Curaçaoan governments and civil society experience a range of economic, institutional, and occasionally technical obstacles to sustainable development, over which they can exert only limited control. However, they do have the responsibility, and to a large extent the capability, to formulate and implement policy in a manner that reflects and represents, rather than contradicts, the local sociocultural context.

While many supralocal efforts underline the need for "awareness raising" and "environmental education," respondents appear to have extensive, intimate knowledge of certain environmental problems and are quite aware of the negative impacts such problems can have. They display a fairly comprehensive outlook on environmental problems such as wastewater and solid waste management, recognizing various aspects of the problems at both the government and the community level, including organizational, technical, and financial constraints as well as the necessity of cooperation between citizens and government. Local-level priorities lie with brown urban environmental problems, which are not seen as isolated from other problems affecting the broader "urban environment." Residents of the four research neighborhoods include other local problems - which they connect to their class and ethnic position within the city - in a model of urban environment I call urban blight (see Jaffe 2006). The disconnect of supralocal policies is compounded by the fact that many NGO and government staff - the environmental "messengers" - are separated socially and spatially from the reality of urban blight. Supralocal environmental perceptions, organization, and action are linked to groups consisting of often light-skinned middle classes or elites, and are shaped by global networks of support and pressure.

The data presented here suggest that the incorporation of local-level environmental perceptions and folk ecologies might increase the relevance of environmental policy and campaigns. On both islands, the government's environmental policies and the strategies used by environmental NGOs focus largely on green environmental issues. While the government does to some extent focus on sewerage, solid waste management, and air pollution, ENGOs for the most part ignore these brown issues. Both government and ENGO environmental education campaigns concentrate on protecting and conserving the green natural environment, underemphasizing the links between the urban and wider environment as well as connections between the social and 
the physical environment. Public education efforts fail to establish the dayto-day relevance of environmental problems for large segments of the population: the danger is that the environment and environmental problems are seen as the realm of a foreign-oriented elite.

Tackling environmental problems will need to involve a more integrated approach, which takes emic perceptions of the urban environment into consideration. Community perceptions of environment and nature imply a shift of environmental policy focus from green to brown problems and to cease seeing these problems as distinct from social concerns. Doing this entails conceiving environmental policy and public education campaigns that involve local perceptions of urban social and public space as well as nature, and incorporating urban environmental problems with social and economic issues. This could mean highlighting the fact that clean and safe neighborhoods and public space go hand in hand with progress in health and development. Additionally, emphasis could be placed on the shared responsibility of government and citizens for creating and maintaining clean, healthy, and safe surroundings that contribute to individual, neighborhood, and national development. On the one hand, using such an approach in environmental campaigns will help emphasize the day-to-day relevance of environmental problems, correcting the misconception of the environment as a luxury concern. On the other hand, this strategy will entail tackling environmental problems not separately, but in the context of providing or improving social development (employment and education), physical infrastructure (housing, streets, lighting) and physical safety, for instance in an environmental justice framework.

Residents in both Jamaica and Curaçao tie views on nature and green environmental issues to religious worldviews, in which a limits to growth concept is conspicuously absent. Government and environmental NGOs must ensure that their approach is relevant to the citizens' cultural understanding of their environment. This might imply appealing to religion-based environmental worldviews next to the dominant scientific environmentalist discourse. On the basis of the data presented here, this could mean drawing on the existing idea of interconnectedness between humans and nature, or stressing the element of care and responsibility in religiously inspired ideas of dominion over nature. Both religious institutions and popular culture might be logical sites for environmental messengers and messages. In mainstream scientific discourse or environmental education, the findings presented here could be incorporated by making a more convincing case for limits to growth, for instance on the basis of the practical experience of environmental disasters such as floods. Taking into account the instrumental value placed on nature suggests accentuating the health and developmental impacts of environmental degradation - this might be more effective than trying to persuade the population to change its behavior on account of nature's intrinsic value. 
Especially in countries where governments struggle to make the most of scarce resources, it is imperative to seek the cooperation of the local population, acknowledging and utilizing their perspectives and worldviews. Rather than focusing on re-educating Caribbean populations toward a western concept of environmentalism, supralocal organizations and environmental professionals must actively seek to use discourse and apply approaches that are relevant to all segments of the population.

\section{REFERENCES}

ABRAMSON, ALLEN, 2000. Mythical Land, Legal Boundaries: Wondering about Landscape and Other Tracts. In Allen Abramson \& Dimitrios Theodossopoulos (eds.), Land, Law and Environment: Mythical Land, Legal Boundaries. London: Pluto Press, pp. 1-30.

Austin-Broos, Diane J., 1997. Jamaica Genesis: Religion and the Politics of Moral Orders. Chicago: University of Chicago Press.

BARrow, Christine, 1992. Family Land and Development in St. Lucia. Cave Hill, Barbados: ISER, UWI.

BESSON, JEAN \& JANET MOMSON (eds.), 1987. Land and Development in the Caribbean. London: Macmillan Caribbean.

BONNIOL, JEAN-LUC, 1979. Perceptions of the Environment in a Small Island Community: Terre de Haut des Saintes. In Yves Renard (ed.), Perceptions of the Environment: A Selection of Interpretative Essays. S.1.: Caribbean Conservation Association, pp. 53-68.

CARRIER, JAMES G., 2003. Mind, Gaze and Engagement: Understanding the Environment. Journal of Material Culture 8:5-23.

CheVAnNeS, BARRY, 1994. Rastafari: Roots and Ideology. Syracuse NY: Syracuse University Press.

— \& Herbert Gayle, 1998. Solid Waste Management: Profiles of Inner City Communities in the Kingston Metropolitan Area. Kingston: Faculty of Social Sciences, UWI Mona.

Clarke, Edith, 1957. My Mother Who Fathered Me: A Study of the Family in Three Selected Communities in Jamaica. London: George Allen and Unwin.

CRICHLOW, MichaEline, 1990. An Alternative Approach to Understanding the Phenomenon of Family Land in the Anglophone Caribbean. St. Augustine, Trinidad: Women and Development Studies, Faculty of Engineering, UWI.

-, 1994. An Alternative Approach to Family Land Tenure in the Anglophone Caribbean: The Case of St. Lucia. NWIG 68:77-99.

Desmangles, Leslie G., S.D. Glazier \& J.M. Murphy, 2003. Religion in the Caribbean. In Richard S. Hillman \& Thomas J. D'Agostino (eds.), Understanding the Contemporary Caribbean. Boulder CO: Lynne Rienner, pp. 263-304. 
DODMAN, DAVID R., 2003. Nature, Power and Participation: An Exploration of Ecology and Equity in Kingston, Jamaica. PhD Thesis, University of Oxford.

Douglas, MARY, 2002. Purity and Danger: An Analysis of Concepts of Pollution and Taboo. London: Routledge.

Dunlap, Riley E., Kent D. VAn Liere, Angela G. Mertig \& Robert EMmet JONES, 2000. Measuring Endorsement of the New Ecological Paradigm: A Revised NEP Scale. Journal of Social Issues 56:425-42.

EDMONDS, ENNIS BARRINGTON, 1998. The Structure and Ethos of Rastafari. In Nathaniel Samuel Murrell, William D. Spencer \& Adrian Anthony McFarlane (eds.), Chanting Down Babylon: The Rastafari Reader. Philadelphia PA: Temple University Press, pp. 349-60.

Gmelch, GeOrge, 2003. Behind the Smile: The Working Lives of Caribbean Tourism. Bloomington: Indiana University Press.

HAAS, PETER M., 1992. Introduction: Epistemic Communities and International Policy Coordination. International Organization 46:1-35.

HARPER, Douglas, 2002. Talking about Pictures: A Case for Photo Elicitation. Visual Studies 17:13-26.

HeAdley, Bernard, 2002. A Spade is Still a Spade: Essays on Crime and the Politics of Jamaica. Kingston: LMH.

JÁCOME, Francine, 2006. Environmental Movements in the Caribbean. In Sherrie L. Baver \& Barbara Deutsch Lynch (eds.), Beyond Sun and Sand: Caribbean Environmentalisms. New Brunswick NJ: Rutgers University Press, pp. 17-31.

JAFFE, RIVKE, 2006. Urban Blight in the Caribbean: City, Environment and Culture in Curaçao and Jamaica. PhD Thesis, Leiden University, the Netherlands.

Kalof, Linda, Thomas Dietz, Gregory Guagnano \& Paul C. Stern, 2002. Race, Gender and Environmentalism: The Atypical Values and Beliefs of White Men. Race, Gender and Class 9:1-19.

Kruijf, Hans de \& Harold Arends, 1975. The Attitude of the People in Curaçao towards "Naturalesa": A Qualitative Psychological Study. Kristòf 2:205-12.

LEVY, CATHERINE, 1996. The Environmental NGO Movement in Jamaica. Jamaica Journal 26:22-25.

LOWENTHAL, DAVID, 1961. Caribbean Views of Caribbean Land. Canadian Geographer 2:1-9.

LUNDY, PATRICIA, 1999. Fragmented Community Action or New Social Movement? A Study of Environmentalism in Jamaica. International Sociology 14:83-102.

MCGranahan, Gordon \& DAVID SATterThwaite, 2002. Environmental Health or Ecological Sustainability? Reconciling the Brown and Green Agendas in Urban Development. In Roger Zetter \& Rodney White (eds.), Planning in Cities: Sustainability and Growth in the Developing World. London: ITDG Publishing, pp. 43-57. 
MCKee, David L. \& Clem A. Tisdell, 1990. Developmental Issues in Small Island Economies. New York: Praeger.

MiLTON, KAY, 1996. Environmentalism and Cultural Theory: Exploring the Role of Anthropology in Environmental Discourse. London: Routledge.

NADASDY, PAUL, 2005. Transcending the Debate over the Ecologically Noble Indian: Indigenous Peoples and Environmentalism. Ethnohistory 52:291-331.

PotTer, RoBert B., 1992. Caribbean Views on Environment and Development: A Cognitive Perspective. Caribbean Geography 3:236-43.

-, 2000. The Urban Caribbean in an Era of Global Change. Aldershot: Ashgate.

RauWAld, Kimberley S. \& COlleEn F. MoORe, 2002. Environmental Attitudes as Predictors of Policy Support across Three Countries. Environment and Behavior 34:709-39.

Ringel, GAIL \& JONATHAN WYLIE, 1979. God's Work: Perceptions of the Environment in Dominica. In Yves Renard (ed.), Perceptions of the Environment: A Selection of Interpretative Essays. S.1.: Caribbean Conservation Association, pp. 39-50.

RYDIN, YvonNe, 1999. Can We Talk Ourselves into Sustainability? The Role of Discourse in the Environmental Policy Process. Environmental Values 8:467-84.

SKelton, TRACEY, 1996. "Cultures of Land" in the Caribbean: A Contribution to the Debate on Development and Culture. European Journal of Development 8:71-92.

Stern, PAul C., ThOmAs DietZ \& GREGORY A. GuagnANO, 1995. The New Ecological Paradigm in Social-Psychological Context. Environment and Behavior 27:723-43

STREEFKERK, CORNELIS, 2003. Beeldvorming en religie. In Rose Mary Allen, Coen Heijes \& Valdemar Marcha (eds.), Emancipatie en acceptatie: Curaçao en Curaçaoënaars: beeldvorming en identiteit honderdveertig jaar na de slavernij. Amsterdam: SWP, pp. 35-50.

TAYLOR, PATRICK (ed.), 2001. Nation Dance: Religion, Identity and Cultural Difference in the Caribbean. Bloomington: Indiana University Press.

THOMAS-HoPe, EliZABeTH M., 1996. The Environmental Dilemma in Caribbean Context. Grace, Kennedy Foundation Lecture. Kingston: The Grace, Kennedy Foundation.

VERHEIJ, BERT, 2001. Grass between the Tiles: Man and Nature on Saba. Masters Thesis, Leiden University, the Netherlands.

Williams, Colin C. \& Andrew C. Millington, 2004. The Diverse and Contested Meanings of Sustainable Development. Geographical Journal 170:99-104.

RIVKE JAFFE

Department of Sociology, Psychology and Social Work

University of the West Indies

Mona, Jamaica

<rivke.jaffe@uwimona.edu.jm> 